\title{
Structure and dynamics of a Cariniana estrellensis (Lecythidaceae) population in a fragment of Atlantic Forest in Minas Gerais, Brazil ${ }^{1}$
}

Estrutura e dinâmica de uma população de Cariniana estrellensis (Raddi) Kuntze (Lecythidaceae) em um fragmento de Floresta Atlântica em Minas Gerais, Brasil

\author{
Yule Roberta Ferreira Nunes ${ }^{2,4}$ \& Miguel Petrere $\mathrm{Jr}^{3}$
}

\begin{abstract}
We aimed to describe population structure and dynamics of Cariniana estrellensis (Raddi) Kuntze to test the hypothesis that this species survives in the forest by forming a seedling bank. We evaluated seed germination, spatial distribution, and recruitment, growth and mortality rates of young individuals. To characterize population structure a 1.2-ha plot was defined, where reproductive adults were mapped; also $1006 \mathrm{~m}^{2}$ subplots were established to characterize structure and monitor dynamics of young individuals. We estimated seed production using seed collectors and determined the percentage of canopy cover by hemispherical photographs. Seed rain and saplings showed clustered distribution indicating habitat-patch formation. Sapling mortality occurred mainly during the initial establishment phase. Size structure was characterized by many saplings $(\bar{X}$ $=9,763$ individuals $\left.\mathrm{ha}^{-1}\right)$ and few adults $\left(\overline{\mathrm{X}}=5\right.$ individuals $\left.\mathrm{ha}^{-1}\right)$, associated with a high rate of seed production $\left(\bar{X}=60,800\right.$ seeds $\left.^{-1}\right)$, low growth rates $\left(\bar{X}=2.37 \mathrm{~cm}\right.$ ano $\left.^{-1}\right)$ and mortality (15.66\%) of established saplings, showing that species invest in seedling bank formation as a reproductive strategy.

Key words: seedling bank, growth, mortality, canopy cover, "jequitibá".
\end{abstract}

\section{Resumo}

Este trabalho objetivou caracterizar a estrutura e a dinâmica de uma população de Cariniana estrellensis (Raddi) Kuntze, procurando testar a hipótese que a espécie persiste na floresta por meio do banco de plântulas. Foram avaliadas a germinação de sementes, distribuição espacial, e recrutamento, crescimento e mortalidade das plantas jovens. Para caracterizar a estrutura populacional uma parcela de 1,2 ha foi definida, onde foram mapeados os indivíduos adultos, e distribuídas 100 sub-parcelas de $6 \mathrm{~m}^{2}$ para caracterizar a estrutura e monitorar dinâmica dos indivíduos jovens. As sementes foram amostradas através de coletores para estimar sua produção e a porcentagem de cobertura do dossel por fotografias hemisféricas. A chuva de sementes e os juvenis apresentaram distribuição agregada, mostrando a existência de manchas de habitas. A mortalidade dos jovens ocorreu principalmente no estágio inicial de estabelecimento. A estrutura de tamanhos, caracterizada pela ocorrência de grande número de indivíduos jovens $\left(\bar{X}=9.763\right.$ indivíduos ha $\left.{ }^{-1}\right)$ e pequeno número de adultos $\left(\overline{\mathrm{X}}=5\right.$ indivíduos ha $\left.{ }^{-1}\right)$, associada à alta taxa de produção de sementes $\left(\overline{\mathrm{X}}=60.800\right.$ sementes ha $\left.^{-1}\right)$ e a baixas taxas de crescimento $\left(\bar{X}=2,37 \mathrm{~cm}^{2}\right.$ ano $\left.^{-1}\right)$ e mortalidade dos indivíduos jovens estabelecidos $(15,66 \%)$, demostram que a espécie investe na formação de banco de plântulas como estratégia reprodutiva.

Palavras-chave: banco de plântulas, crescimento, mortalidade, cobertura do dossel, jequitibá.

\section{Introduction}

The study of tropical tree population dynamics, in all aspects, has gained much attention in recent decades (Rees et al. 2001), largely due to the alarming rates of habitat loss caused by human pressure on natural resources, the creation of fragmented landscapes (Muthuramkumar et al. 2006), and the wide gap in knowledge of these species (Clark \& Clark 1996). The dynamics of plant populations in a community explains the

\footnotetext{
${ }^{1}$ Part of the Master Thesis of the first author developed in Ecology, Conservation and Management of Wildlife Graduate Program, Universidade Federal de Minas Gerais, MG, Brazil.

${ }^{2}$ Universidade Estadual de Montes Claros, Depto. Biologia Geral, Lab. Ecologia e Propagação Vegetal, Campus Universitário Prof. Darcy Ribeiro, Vila Mauricéia, CP 126, 39401-089, Montes Claros, MG, Brazil.

${ }^{3}$ Universidade Estadual Paulista Júlio de Mesquita Filho, Depto. Ecologia, Instituto de Biociências de Rio Claro, Av. 24A n. 1515, Bela Vista, CP 199, 13506900, Rio Claro, SP, Brazil.

${ }^{4}$ Corresponding author: yule.nunes@unimontes.br
} 
qualitative and quantitative changes that occur in vegetation (Harper 1977). Thus, the occurrence and spatial distribution of tree species in a forest are determined, in part, by fruiting periods, dispersal strategies, and seed germination (Alves $\&$ Metzger 2006). In addition, the differential response of plants to light (or shade tolerance) defines different population structures (Zavala et al. 2007). Therefore, despite the absence of individuals in some, or even many, size classes observed in specific areas in several populations of emerging tree species (e.g. Clark \& Clark 1984; Clark \& Clark 1987), there is a wide interdependence between seed, seedling and adult stages of these species, which determines their complex life histories (Clark \& Clark 1996; Pooter et al. 1996; Laurance et al. 2004; Grogan et al. 2005).

Emergent trees are a group of species that have common physiological and ecological characteristics (Clark \& Clark 1987). This group has special features such as large tree trunks and tall stature (usually diameter at breast height $>70 \mathrm{~cm}$ and height $>31 \mathrm{~m}$ in tropical rain forests), which allows these trees to occupy the emergent stratum (Oliveira et al. 2008), and dispersal mechanisms related to this stature (e.g., anemocoric and ornithocoric) (Howe \& Smallwood 1982; Swaine \& Whitmore 1988; Santos et al. 2008). These are characteristically light-demanding climax species (sensu Swaine \& Whitmore 1988) and are able to germinate in light or shade, but require high levels of brightness to optimize initial growth. Later, they can tolerate the shade of the understory (Grogan et al. 2005) through the formation of a seedling or immature plant bank (Swaine \& Whitmore 1988). Although this group of trees usually represents less than $10 \%$ of species richness in tropical forests, they contribute disproportionately to biomass, nutrient cycling, and carbon storage in soils (Oliveira et al. 2008). In addition, emergent trees are considered key food and shelter sources for several species of birds and primates (Oliveira $e t$ al. 2008). The demographics of tropical emergent species remain largely unknown, especially when it comes to factors that determine the low density of post-seedling or immature stages and, in many cases, intermediate stages, which are rare and poorly sampled (Knight 1975; Clark \& Clark 1987, 2006).
Considering the structure of emergent tree populations, there are two main hypotheses used to explain the low adult/seedling ratio and the rarity of intermediate stages. The first assumes that adults are relics of a large disturbance or forest removal in the past (Knight 1975). In this case, the species are relics and no longer belong to the climax forest community (Knight 1975). Evidence in favor of this hypothesis relates to a gap in the structure of the adult population and the occurrence of few individuals from the juvenile stage (Clark \& Clark 1987). The second hypothesis theorizes that the emerging species depend on periodic natural gaps in the canopy resulting from falling trees, landslides, or floods as locations for growth and seedling establishment (Hubbell \& Foster 1987). Such an establishment would be rare and would most likely be associated with rapid growth in juvenile stages, thus producing the gaps found in the population structure (Knight 1975; Clark \& Clark 1987; Clark \& Clark 2001). This process must lead to a continuous distribution of size classes and, despite being scarce, the juveniles should be present if a large enough area is sampled (Clark $\&$ Clark 1987).

In general, the seeds of tropical trees exhibit rapid germination rates and low rates of viability (Hladik \& Mitja 1996). Dormancy is also characteristic of a few tropical tree species (Baskin \& Baskin 1998). Seedlings of these species can survive for many years, waiting for more favorable growth conditions (Salles \& Schiavini 2007). In tropical forests, the tree-fall gaps provide suitable sites for the establishment and growth of tree species (Lima 2005). Thus, two recruitment scenarios may cause a multimodal population structure (Zavala et al. 2007) of emergent trees: (i) seed germination in the understory and accelerated growth from a disturbance event causing an opening in the canopy, or (ii) seed dispersal into newly formed canopy gaps, with germination and initial growth of seedlings at this location (Grocan et al. 2005).

Cariniana estrellensis (Raddi) Kuntze, popularly known as jequitibá, is a non-pioneer or climax tree species (sensu Swaine \& Whitmore 1988), with height usually exceeding the forest canopy and is considered an emergent tree (Mori $\&$ Prance 1990). The seeds of C. estrellensis do not seem to have a dormancy period and can 
germinate in the dark (Nunes \& Ribeiro 1999). Trees with these characteristics typically have high mortality rates after germination and low growth rates under a closed canopy (Peres \& Baider 1997; Mack et al. 1999; Grogan et al. 2005), suggesting the formation of a seedling bank (Mack et al. 1999). In this study, we characterized the population structure of $C$. estrellensis through studies of seed germination, seedling recruitment, survival, growth, and spatial distribution. We tested the hypothesis that C. estrellensis, an emergent species, depends on natural openings in the canopy for recruitment from the seedling bank, producing gaps in the population structure.

\section{Materials and Methods}

\section{Study area}

This study was conducted in the Special Protection Area of Barreiro (SPA-Barreiro), which, combined with other SPA areas, forms the RolaMoça State Park. The SPA-Barreiro, located in Belo Horizonte (Minas Gerais state, Brazil), with 1,406 ha (Fig. 1), is situated between the Atlantic
Forest and the Cerrado dominium, where distinct ecosystems of savannas (cerrado), rocky fields (campos rupestres) and gallery forests occur (Meyer et al. 2004). The work was performed in a stretch of gallery forest located on the right bank of

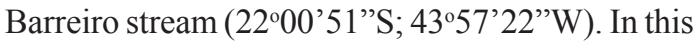
region, inceptisols and entisols are predominant, with texture ranging from sandy to clay, in a strongly undulating, hilly topography (Meyer et al. 2004). The climate is Cwa (humid subtropical) of Köppen, with dry winters and wet summers, average annual temperature of $19^{\circ} \mathrm{C}$ and average rainfall of $1400 \mathrm{~mm} /$ year (Fig. 2), with $50 \%$ of the rain occurring from December to February (Meyer et al. 2004).

\section{Study species}

Cariniana estrellensis (Raddi) Kuntze (Lecythidaceae) is popularly known as jequitibá, jequitibá-branco, jequitibá-rei, estopeira, or cachimbeiro (Rizzini 1971). It is an arboreal species and generally reaches $20-25 \mathrm{~m}$ in height, but can exceed $50 \mathrm{~m}$, with a diameter at breast height $(\mathrm{DBH})$ of 30 to $50 \mathrm{~cm}$ (Prance \& Mori
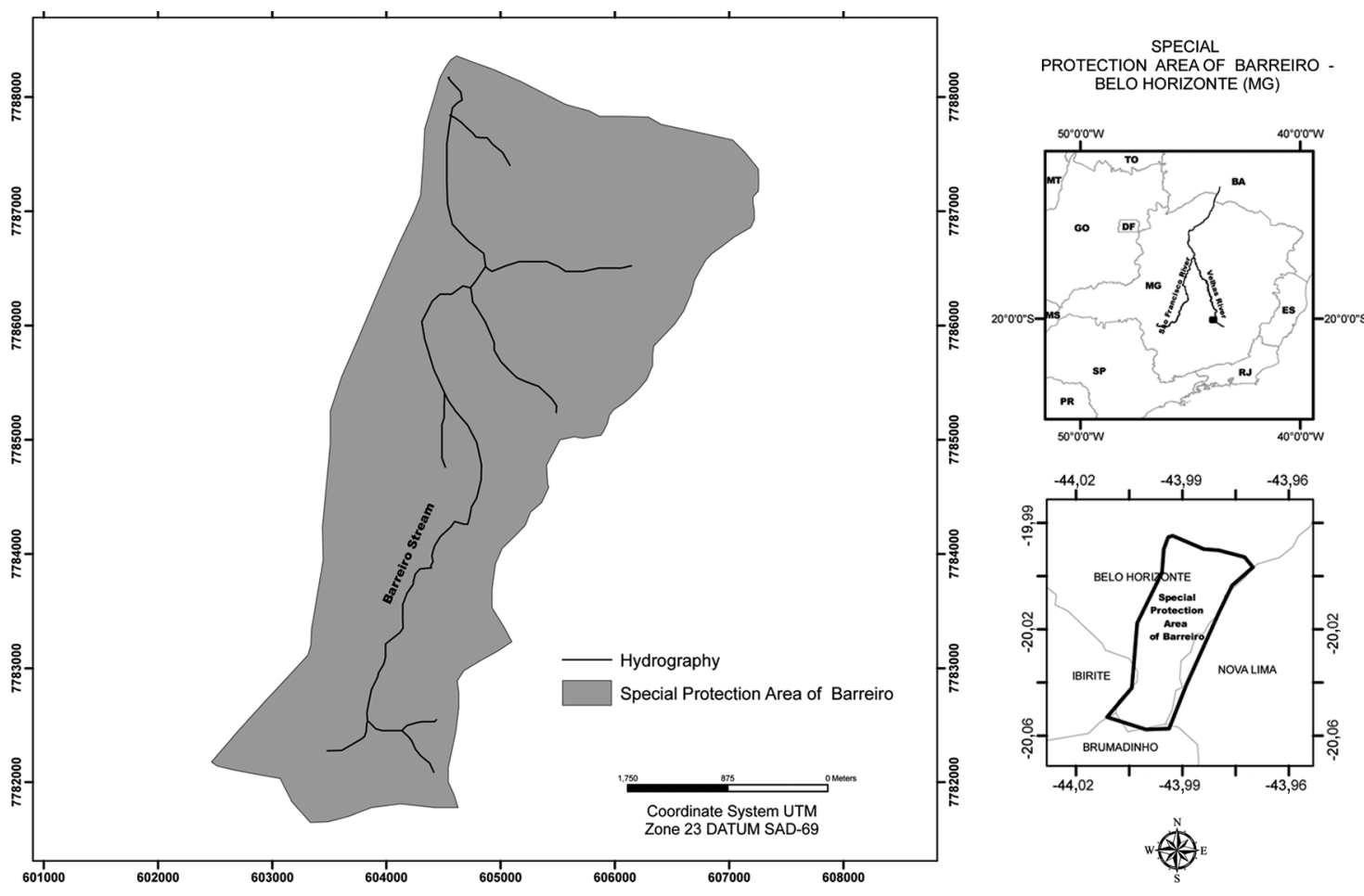

Figure 1 - Location of the sample area in the Special Protection Area of Barreiro (Rola Moça State Park), Belo Horizonte, MG. 
1979). The trunk is fairly straight, with thick bark, split vertically (Prance \& Mori 1979; Reitz 1981). The canopy is formed by nearly vertical branches and foliage is sparse and deciduous (Prance \& Mori 1979). It has simple, oblong-elliptical to lanceolate leaves $(5-15 \mathrm{~cm}$ in length $\times 1.5$ to 6 $\mathrm{cm}$ wide) with serrated margins and small, creamy white flowers, clustered in axillary racemes with 5-15 flowers. The fruit is a cylindrical-oblong, woody, brown fibrous pyxis $(5-11 \mathrm{~cm}$ long $\times$ $3-4 \mathrm{~cm}$ in diameter) with 20 to 35 brown seeds with membranous wings (Carvalho 2003). It is distinguished from other species in the genus by the axillary inflorescence and teeth around the line of dehiscence on the pyxis (Prance \& Mori 1979). Cariniana trees are emergent or canopy trees (Mori \& Prance 1990). The tall stature and seed morphology may be related to anemochory, especially when the tree has no leaves (Mori \& Prance 1990). Cariniana estrellensis occurs mainly in central Brazil (Distrito Federal, Bahia, Minas Gerais, Rio de Janeiro and São Paulo) but also in Acre, Paraná and Santa Catarina (Prance \& Mori 1979; Reitz 1981).

\section{Population structure and dynamics}

To characterize the population structure of C. estrellensis, a single plot $80 \times 150 \mathrm{~m}(1.2 \mathrm{ha})$ was defined as the study area, where we sampled all reproductive adult individuals in the plot. Adults were considered to be individuals that had a reproductive event during the study period (from August 1997 to September 1998). For

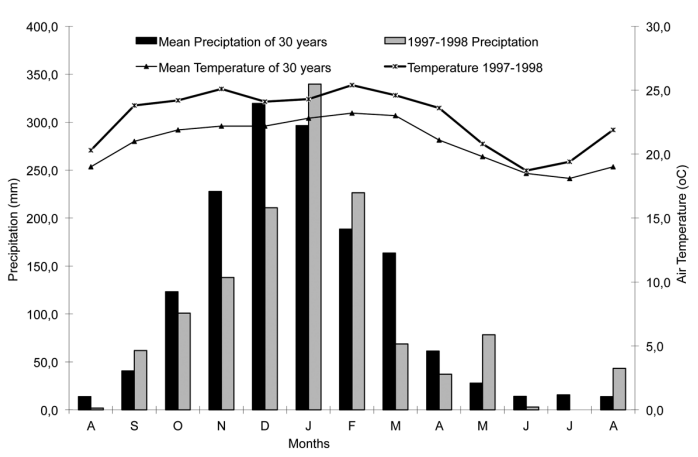

Figure 2 - Average monthly precipitation and temperature between August 1997 and August 1998 and climatological norms of 30 years for Belo Horizonte region (Minas Gerais, Brazil). Source: National Institute of Meteorology of Belo Horizonte. these individuals, we measured total height and calculated DBH by measuring the circumference at $1.3 \mathrm{~m}$ above ground. The height was estimated using the stages of a trimmer and the circumference was measured with a tape measure.

In the 1.2 ha plot 100 sub-plots $2 \times 3 \mathrm{~m}$ were randomly distributed in order to characterize structure and dynamics of young individuals in the study area. These sub-plots formed a 5\% $\left(600 \mathrm{~m}^{2}\right)$ sample of the total experimental area. Trees were considered to be young if they had $\mathrm{DBH}<5 \mathrm{~cm}$ and/or height $<3 \mathrm{~m}$. The seedlings of C. estrellensis were identified by visual analysis of the morphological characteristics of the leaf-like cotyledons (Mori \& Prance 1990). In these subplots, all saplings of $C$. estrellensis were marked and monitored in quarterly measurements, which occurred in August and December, 1997, and April and August, 1998. Individual trees were marked with plastic numbered tags, which were attached by nylon cords. Diameter at the base of the stem (DBS) and total height were measured with calipers and yardsticks, respectively. New individuals recruited from the previous sampling period were marked, measured, and included. In addition, dead individuals were recorded and the survivors were measured again.

Seed rain, germination, and recruitment

To determine the relationship between the number of seeds produced and recruitment of $C$. estrellensis seedlings, seed production in the study area was estimated per hectare from seeds collected monthly in 100 wood collectors $(50 \times 50 \times 20 \mathrm{~cm})$ with nylon screens $(2 \mathrm{~mm})$, during the same monitoring period of the young individuals dynamics, which were installed in adjacent sub-plots. Additionally, percent germination of the seeds was determined by evaluating the viability of 100 seeds collected from the forest litter in September, 1998. The seeds were germinated in an incubator with controlled temperature and photoperiod (12:12 hour photoperiod; $30^{\circ} \mathrm{C}$ light: $20^{\circ} \mathrm{C}$ dark). The seeds were divided into four replicates of 25 seeds each in a germination box with $1.0 \mathrm{~cm}$ of foam on filter paper and kept moist with 30.0 $\mathrm{ml}$ of distilled water. The seeds were monitored at 24-hour intervals for 30 days. Viable seeds were those that germinated when there was a protrusion of the radical (Borges \& Rena 1993). 


\section{Growth and mortality}

To understand if the dynamics of the young plants (recruitment, growth and survival) were associated with changes in the forest canopy, percent canopy cover in each sub-plot was recorded by hemispherical photographs (Whitmore et al. 1993). The pictures were taken in February 1998 with an 8 -mm fisheye lens, on cloudy days. The pictures were developed, digitalized and transformed into bitonal images (black and white) and processed in WINPHOT version 2.1 (ter Steege 1993), which provided the percentages of canopy cover.

\section{Data analysis}

The density of adult individuals was measured by counting the plants in the plot. The distribution of these individuals was evaluated visually, by plotting the coordinates of each plant on a representative sketch of the plot. The density of young trees was determined by the average number of individuals recorded in the four sampling periods. The distribution pattern of young trees in the different sampling periods was obtained by comparing the observed distribution with a Poisson distribution by the chi-square test (Zar 1996).

Recruitment and mortality were measured by counting the number of individuals recruited and dead, in each sub-plot, during each time interval. Growth was determined using differences in final and initial heights of the young trees in the different periods and for the total sample period (one year). Mortality was calculated as the ratio of the number of deaths to the initial number of individuals in each sample. There was a significant relationship between height and basal diameter of the plants $\left(\mathrm{y}=-5.273+87.706 \mathrm{x}, \mathrm{p}<0.001, \mathrm{r}^{2}=\right.$ $0.723, \mathrm{n}=664)$. Thus, only the height of young trees was used to estimate growth. Young trees were divided into seven arbitrary height classes (class I: $>0.0-\leq 0.2 \mathrm{~m}$; class II: $>0.2-\leq 0.4 \mathrm{~m}$; class III: $>0.4-\leq 0.6 \mathrm{~m}$; class IV: $>0.6-\leq 0.8 \mathrm{~m}$; class $\mathrm{V}:>0.8-\leq 1 \mathrm{~m}$; class $\mathrm{VI}:>1-\leq 1.5 \mathrm{~m}$; class VII: $>1.5-\leq 3 \mathrm{~m}$ ). Differences in recruitment, growth and mortality between classes and between sampling periods were detected using ANOVA and Tukey's tests (Zar 1996). The effect of canopy cover on the growth and mortality of young plants was evaluated using linear regression (Zar 1996). All the data was first tested for normality using Kolmogorov-Smirnov test (Zar 1996).
The distribution pattern of seed rain was obtained by comparing the distribution observed with a Poisson distribution in a chi-square test (Zar 1996). The effects of seed rain and percent forest canopy on recruitment were estimated using linear regression (Zar 1996).

\section{Results}

Population structure and dynamics

There were six reproductive $C$. estrellensis adults in a 1.2 ha area, corresponding to a density of five individuals/ha. Average height and DBH of adult plants were $25.0 \mathrm{~m}( \pm 1.7 \mathrm{~m})$ and $1.9 \mathrm{~m}$ $( \pm 0.7 \mathrm{~m})$, respectively. The visual arrangement of these individuals indicates a clustered distribution pattern. During the four collections, we sampled 664 C. estrellensis saplings, an average of 585.8 $( \pm 51.9)$ per sampling period. This average indicates a density of 9,763 individuals/ha. The smallest and largest trees sampled were $0.06 \mathrm{~m}$ and $2.85 \mathrm{~m}$ tall, respectively. The smallest DBS was $0.10 \mathrm{~cm}$ and the largest was $2.70 \mathrm{~cm}$. Young individuals showed a clustered distribution pattern in all of the sampling periods (August/97: $\chi_{7,0.95}^{2}=$ 35.43, $\mathrm{n}=100$; December/97: $\chi_{7,0.95}^{2}=25.94, \mathrm{n}=$ 100; April/98: $\chi_{7,0.95}^{2}=20.66, \mathrm{n}=100$; August/98: $\chi_{7,0.95}^{2}=20.74, \mathrm{n}=100$ ).

The frequency distribution of $C$. estrellensis individuals in each height class follows a negative exponential curve (Fig. 3). After one year of monitoring, most of the sampled individuals $(62.4 \%)$ remained in the same height class. Transfers to taller classes occurred in $31.5 \%$ of the population of young individuals. The remaining individuals showed negative growth because the main stems dried out and moved down to lower height classes $(6.1 \%)$.

The number of young trees varied between height classes $(\mathrm{F}=50.854, \mathrm{p}<0.001, \mathrm{n}=700)$ (Tab. 1). The average number of individuals in height classes I and II did not differ, but both classes were more frequent than all others. Classes V, VI, and VII reported the lowest mean numbers of individuals. Considering this distribution, $60.35 \%$ of all individuals were less than $0.4 \mathrm{~m}$ tall. Individuals in classes ranging from 0.4 to $1 \mathrm{~m}$ accounted for $34.03 \%$ of the population, whereas young trees from classes VI and VII (from 1 to $3 \mathrm{~m}$ ) represented only $5.57 \%$ of all individuals. Individuals that reached reproductive adulthood represented $0.05 \%$ of the sampled population. 


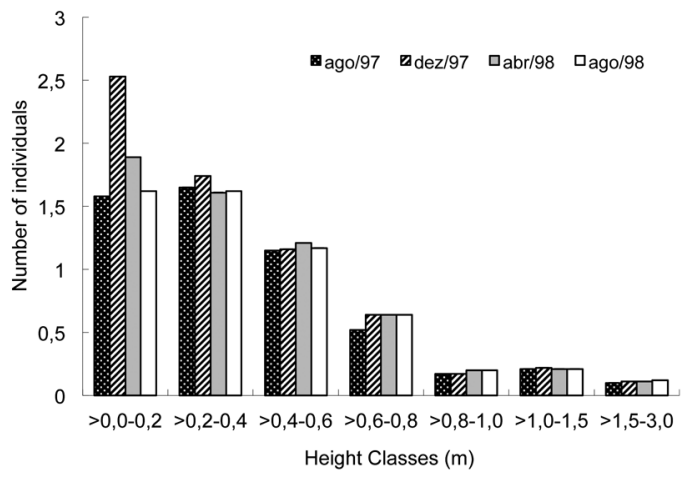

Figure 3-Variation between sampling periods in the average number of Cariniana estrellensis saplings in each sub-plot, in the Special Protection Area of Barreiro (Rola Moça State Park), Belo Horizonte, MG.

Moreover, we noted that individuals between 3 and $23 \mathrm{~m}$ in height were not found.

Considering the different height classes separately, only the first class exhibited differences in the number of individuals between sampling periods (Fig. 3). These differences are primarily due to recruitment that occurred in December, 1997. Recruitment during this period was followed by high rates of mortality of the recruited individuals, slowing over time and practically returning to the initial recruitment level in August, 1998.

Seed rain, germination, and recruitment

During the sampling periods, 152 seeds were collected in the seed collectors, equaling 60,800 seeds/ ha. These seeds in the collectors exhibited a clustered distribution pattern $\left(\chi_{5,0.95}^{2}=38.59, \mathrm{n}=100\right)$.

The percentage of $C$. estrellensis seeds that germinated in the laboratory was $56 \%$. Based on this germination rate, expected recruitment from seed rain would be 34,048 seedlings/ha. However, recruitment observed in the field (126 seedlings) corresponded to only 2,100 seedlings/ha, with a loss of $93.8 \%$ of the seed rain.

The number of recruited individuals was poorly correlated with canopy openness $(\mathrm{y}=0.265$ $+0.142 \mathrm{x}, \mathrm{p}=0.001, \mathrm{r}^{2}=0.100, \mathrm{n}=100$ ), showing that recruitment increases slightly in areas that receive more light. However, canopy openness only explained $10 \%$ of variation in recruitment. Recruitment also showed poor correlation with seed rain per collector $(\mathrm{y}=0.289+0.155 \mathrm{x}, \mathrm{p}<$ $0.001, \mathrm{r}^{2}=0.123, \mathrm{n}=99$ ), that explained only $12.3 \%$ of the observed variation in recruitment.
Growth and mortality

Saplings of C. estrellensis grew an average of $2.39 \mathrm{~cm}( \pm 8.11 \mathrm{~cm})$ in one year. The annual growth varied between height classes $(F=$ $2.218, p=0.040, \mathrm{n}=566)$. Except for the sixth class $(>1.0-\leq 1.5 \mathrm{~m})$, the height classes showed positive growth (Fig. 4). However, the growth rate of young trees showed no significant relationship with canopy openness $(y=-0.016+$ $\left.0.192 \times, p=0.064, r^{2}=0.036, n=96\right)$.

Young individuals also exhibited differences in growth between sampling periods $(F=32.670, p=0.000, \mathrm{n}=1516)$. In general, the highest amount of growth was observed during the period from August to December 1997, which is characterized by a dry season and an early rainy season (Fig. 2). In the next season, between December 1997 and April 1998, the young plants exhibited relatively low average growth rates. The last sample, taken after typically drier months (April-August, 1998), recorded negative average growth rates (Fig. 4), caused by the reduction in size of individuals from stems becoming desiccated and dying. The individuals in classes I, II, and III were the only trees that showed growth differences between sampling periods. This difference occurred only between the first period (August-December, 1997) and the following periods (December, 1997, to April, 1998; and April-August, 1998).

Mortality of C. estrellensis saplings during the sample period was $15.6 \%$. In this period, 99 of the 104 individuals that died belonged to the first height class $(95.2 \%)$ and five belonged to the second class $(4.8 \%)$. The other classes did not suffer losses during the sampling periods. Changes in the number of individuals of these classes were solely due to the growth of individuals. Seedling mortality reached $68.3 \%$ of recruited individuals. Hence, mortality was greater in the early stage of seedling establishment. Mortality was poorly correlated with percentage of canopy opening $(\mathrm{y}=0.191-$ $\left.0.004 \mathrm{x}, \mathrm{p}=0.008, \mathrm{r}^{2}=0.076, \mathrm{n}=92\right)$, tending to decrease in areas that receive more light. However, canopy openness explained only $7.6 \%$ of the variation in mortality.

The number of dead trees varied between sampling periods $(F=11.630, p<0.001, \mathrm{n}=$ 286 ). Mortality in the first period (August- 
Table 1 - Mean number and mean height ( \pm standard deviation) of Cariniana estrellensis (Raddi) Kuntze saplings in the height classes, per hectare, in APE-Barreiro (Rola Moça State Park), Belo Horizonte, MG.

\begin{tabular}{cccc}
\hline $\begin{array}{c}\text { Height } \\
\text { Classes }(\mathbf{m})\end{array}$ & $\begin{array}{c}\text { Mean Number of } \\
\text { Individuals } \pm \text { SD }\end{array}$ & $\begin{array}{c}\text { \% Individuals } \\
\text { Height Classes }\end{array}$ & $\begin{array}{c}\text { Mean Height (m) } \\
\pm \text { SD }\end{array}$ \\
\hline $1(>0.0-0.2)$ & $30.50 \pm 22.83$ & 32.50 & $0.12 \pm 0.04$ \\
$2(>0.2-0.4)$ & $27.50 \pm 28.83$ & 28.30 & $0.30 \pm 0.06$ \\
$3(>0.4-0.6)$ & $19.50 \pm 18$ & 20.10 & $0.49 \pm 0.06$ \\
$4(>0.6-0.8)$ & $10.17 \pm 15$ & 10.40 & $0.69 \pm 0.05$ \\
$5(>0.8-1)$ & $3.00 \pm 6$ & 3.20 & $0.89 \pm 0.06$ \\
$6(>1-1.5)$ & $3.50 \pm 7.17$ & 3.60 & $1.30 \pm 0.14$ \\
$7(>1.5-3)$ & $1.83 \pm 5$ & 1.90 & $2.17 \pm 0.45$ \\
Total & $105.33 \pm 102.83$ & 100 & $0.36 \pm 0.36$ \\
\hline
\end{tabular}

December, 1997) was $0.7 \%$ (four individuals). Higher mortality rates were recorded between December 1997 and April 1998, with a decrease of $9.2 \%$ (71 individuals) in the number of young individuals. Mortality of the newly recruited seedlings accounted for $94.4 \%$ of the total loss during this period. Between April and August 1998, 29 individuals died, which was $4.4 \%$ of the total sapling population. Of this total, 25 individuals belonged to the first height class and four to the second class. The recruited seedlings suffered greater losses, with up to $76 \%$ dying during the period.

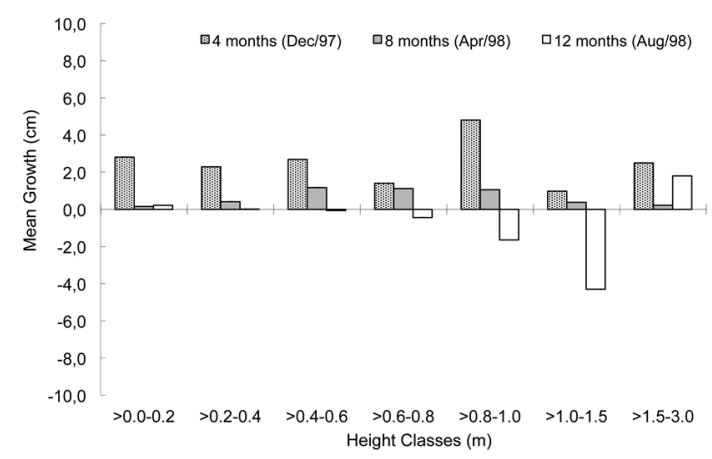

Figure 4 - Average growth of young Cariniana estrellensis individuals in different height classes, at four-month intervals, at the Special Protection Area of Barreiro (Rola Moça State Park), Belo Horizonte, MG.

\section{Discussion}

The distribution of the C. estrellensis sapling population was clustered. In fact, patchy distribution of forest species often relates to the occurrence of habitat patches of different qualities and sizes (Condit et al. 1998). These differences may be related mainly to microtopographic variation and soil structure (Oliveira-Filho et al. 1994; Harms et al. 2004), differential accumulation of biomass on the forest floor (Molofsky \& Augspurger 1992; Dupuy et al. 2008), and variation in intensity of light reaching the forest understory (Augspurger 1984; Montgomery 2004).

Seed dispersal mechanisms may also affect the distribution pattern of individuals in a population (Wada \& Ribbens 1997). For example, seed rain of wind-dispersed plants is concentrated near the matrix, producing an aggregated pattern of newly recruited seedlings (Harper 1977). Changes in air flow currents can also concentrate the seed rain in open-forest gaps (Schupp et al. 1989). Cariniana estrellensis seeds have specialization for wind dispersal (Prance \& Mori 1979). This strategy could explain, at least in part, the aggregate distribution of seed rain observed in this study. However, seed grouping is not necessarily the main determinant of clustered distribution of seedlings, since the seed rain explained only $12.3 \%$ of variation in recruitment.

Light is the most important physical factor in the control of seedling development in tropical 
forests (Lee 1996). Generally, late successional trees exhibit shade tolerance and their seeds can germinate even under low light conditions (Baskin \& Baskin 1998). The seeds of C. estrellensis have higher germination rates under conditions of low light (Nunes \& Ribeiro 1999), indicating that seeds of this species can germinate under the forest canopy. However, canopy openness explained only $10 \%$ of the variation in seedling recruitment. Therefore, recruitment can occur under the canopy, but upward growth may depend on canopy gaps (Grogan et al. 2005). Furthermore, the low recruitment rate indicates that other factors must influence germination of seeds in the field. For example, predators and pathogens (Becker \& Wong 1985; Oliveira-Filho \& Galetti 1996) or soil moisture (Denslow \& Hartshorn 1994) may affect seed germination. Additionally, different methods of seed collection, which occurred monthly, and sapling recruitment, conducted at four-month intervals, may have underestimated the rate of recruitment. Seed dispersal usually occurs between July and September (Rizzini 1971), and recruitment was evaluated in December. Thus, it is likely that newly recruited seedlings had died before being sampled during this interval.

Size distribution models that resemble a negative exponential curve (inverted "J") are not uncommon among emerging tree species (Clark \& Clark 1987; Leite \& Solomão 1992; Peres \& Baider 1997; Zavala et al. 2007). Moreover, as emerging adults of the species are rare and usually long-lived, and juveniles grow relatively fast (Laurance et al. 2004), the existence of bimodal or multimodal size distribution patterns can be observed (Zavala et al. 2007). In this context, it would be expected that large juveniles be rarer in the population, because, on the contrary, the adult density would increase over time (Clark \& Clark 1987), as some long-lived species and emergents can obtain high growth rates when in full sunlight in the forest canopy (Laurance et al. 2004). Therefore, the negative exponential curve of the juveniles and the gap in distribution of the observed ages, with rare adults, most likely show that the C. estrellensis population in the study area is stable and not increasing. Nevertheless, studies involving temporal monitoring of this species for a longer period should be conducted to test, mainly, the growth of large juveniles.

Seedling dynamics may also represent evidence of the degree of stability in populations of tree species, since temporal variation in number of individuals determines the size of the population (Silvertown \& Lovett-Doust 1993). In general, species that require higher light intensities produce large amounts of seeds and have high mortality rates of newly recruited seedlings (Still 1996). Considering the different height classes of $C$. estrellensis, only the first class showed variation in the number of individuals between sampling periods. This class represents the dynamics of entry and exit of recruited seedlings and, although a large number of seedlings are recruited after the period of seed production, few individuals survive the first stages of establishment. The number of individuals entering the seedling bank is approximately equal to the sum of losses in all the different height classes of young individuals, showing a balance in the number of individuals in the population.

Three reproductive strategies among tree species stand out (Mack et al. 1999): (1) seed production (seed rain), followed by rapid establishment and growth of seedlings; (2) formation of a seed bank and (3) formation of a seedling bank. For those species that form a seedling bank, canopy openness is the main driving factor for growth of seedlings and juveniles (De Steven 1994; Jardim et al. 2007). The low average growth of young individuals of $C$. estrellensis during the study period probably denotes the formation of a seedling bank. The initial stages of development showed positive growth in all sampling periods. However, the higher height classes $(>0.6 \mathrm{~m})$ showed more modest growth and, in some cases negative growth, caused by the main stem drying and breaking. Therefore, this growth pattern shows that few if any of these individuals will become established as adults if they remain in the same environmental conditions found during the study period. Moreover, the lack of a relationship between growth and canopy structure shows that the canopy openings in the area are not sufficient to trigger rapid growth of young individuals in reaching the forest canopy (King et al. 2006).

Although interspecific variations occur, mortality is usually higher in the early stages of seedling development (Lieberman 1996; Ramos et al. 2005). Survival depends on physiological attributes of species and biotic interactions. 
In general, the effect of pathogens is higher in shaded areas, and fast growth in gaps may reduce the period of susceptibility to pests and diseases (Schupp et al. 1989). In fact, trees that are able to establish themselves are able to survive several years under the forest canopy as a seedling bank (Hart 1995; Clark \& Clark 1987; Leite \& Hay 1989). In this study, canopy openness explained only $6.8 \%$ of young tree mortality. Moreover, the mortality of $C$. estrellensis individuals occurred almost exclusively in the early stages of seedling establishment. However, even though the mortality rate of individuals that managed to become established was low, few juveniles in the upper height classes were sampled. This is probably due to the low growth rate of these individuals in the upper classes, and stems that dried and broke in the driest months of the year, maintaining a population of shorter juveniles (sapling/seedling bank).

The highest mortality was recorded from December 1997 to April 1998, and from April to August 1998. This mortality is probably associated with the fragility of newly recruited seedlings (Becker \& Wong 1985; Clark \& Clark 1987), even if establishment occurs at the most favorable time of year. The location of establishment also represents a crucial point for survival of seedlings (Molofsky \& Augspurger 1992; Harms et al. 2004). Several seeds were observed germinating on leaves or stones on the forest floor, and these sites are unfavorable for seedling survival in the long term. After this stage, the sampled C. estrellensis seedlings experienced a period of drought that may have caused the death of many individuals during the period from April to August 1998.

It is likely that seedlings and saplings of $C$. estrellensis need high light intensities to grow and establish themselves as adults. In fact, seedlings grown in greenhouses showed superior growth to those observed in the field (authors' unpublished data). The study area showed dense and uniform coverage, in agreement with the results of the canopy cover analysis. Therefore, we believe that canopy gaps in the sampled area did not allow sufficient light penetration to promote the establishment and development of young C. estrellensis, explaining, at least in part, the gaps observed in the population structure. Natural or manmade disturbances, however, can trigger the formation of larger gaps, thus enabling development of seedlings and growth of emerging adults.

\section{Acknowledgments}

The authors thank Coordenação de Aperfeiçoamento de Pessoal de Nível Superior - CAPES for a fellowship for the first author, and Programa de Pós-Graduação em Ecologia, Conservação e Manejo de Vida Silvestre/UFMG. We thank Companhia de Saneamento de Minas Gerais COPASA for permission to carry out research in the study area. We especially thank Maria do Carmo B. Teixeira, José Carlos dos Santos, Gilberto Pedralli (in memorian), Sylvia T. Meyer, Valéria L.O. Freitas, Vilmara P.F. Ribeiro, Elde Suely Nogueira, for the invaluable assistance in all stages of this work, and Fundação Centro Tecnológico de Minas Gerais CETEC for logistic support. We also thank Professor Marcílio Fagundes for great help in the data analysis and interpretation. The first author thanks the grant provided by Fundação de Amparo a Pesquisa de Minas Gerais - FAPEMIG (CRA - PPM-00504-10).

\section{References}

Alves, L.F. \& Metzger, J.P. 2006. A regeneração florestal em áreas de floresta secundária na Reserva Florestal do Morro Grande, Cotia, SP. Biota Neotropica 6: 1-26.

Augspurger. C.K. 1984. Light requirements of neotropical tree seedlings: a comparative study of growth and survival. Journal of Ecology 72 : 777-795.

Baskin, C.C. \& Baskin, J.M. 1998. Seeds: ecology, biogeography, and evolution of dormancy and germination. Academic Press, London. 666 p.

Becker, P. \& Wong, M. 1985. Seed dispersal, seed predation, and juvenile mortality of Aglaia sp. (Meliaceae) in lowland dipterocarp rainforest. Biotropica 17: 230-237.

Borges, E.E.L.; Rena, A.B. 1993. Germinação de sementes. In: Aguiar, I.B.; Piña-Rodrigues; F.C.M. \& Figliolia, M.B. (eds.). Sementes florestais tropicais. ABRATES, Brasília. Pp. 83-135.

Carvalho, P.E.R. 2003. Espécies arbóreas brasileiras. Vol. 1. EMBRAPA, Brasília. 1039 p.

Clark, D.A. \& Clark, D.B. 1984. Spacing dynamics of a tropical rain forest: evaluation of the Jazen-Connell model. American Naturalist 124: 769-788.

Clark, D.A. \& Clark, D.B. 2001. Getting to the canopy: tree height growth in a Neotropical Rain Forest. Ecology 82: 1460-1472.

Clark, D.B. \& Clark, D.A. 1987. Population ecology and microhabitat distribution of Dipteryx panamensis, a neotropical rain forest emergent tree. Biotropica 19: 236-244.

Clark, D.B. \& Clark, D.A. 1996. Abundance, growth and mortality of very large trees in neotropical lowland 
rain forest. Forest Ecology and Management 80: 235-244.

Clark, D.B. \& Clark, D.A. 2006. Tree growth, mortality, physical condition, and microsite in an old-growth lowland tropical rain forest. Ecology 87: 2132.

Condit, R., Sukumar, R. Hubbell, S.P. \& Foster, R.B. 1998. Predicting population trends from size distribution: a direct test in a tropical tree community. American Naturalist 152: 496-509.

Denslow, J.S. \& Hartshorn, G.S. 1994. Tree-fall gap environments and forest dynamic processes. In: McDade, L.A.; Bawa, K.S.; Hespenheide, H.A. \& Hartshorn, G.S. (eds). La Selva: ecology and natural history of a neotropical rain forest. Chicago Press, Chicago. Pp. 120-127.

De Steven, D. 1994. Tropical tree seedling dynamics: recruitment patterns and their population consequences for three canopy species in Panama. Journal of Tropical Ecology 10: 369-383.

Dupuy, J.M \& Chazdon, R.L. 2008. Interacting effects of canopy gap, understory vegetation and leaf litter on tree seedling recruitment and composition in tropical secondary forests. Forest Ecology and Management 255: 3716-3725.

Grogan, J; Landis, R.M.; Ashton, M.S. \& Galvão, J. 2005. Growth response by big-leaf mahogany (Swietenia macrophylla) advance seedling regeneration to overhead canopy release in southeast Pará, Brazil. Forest Ecology and Management 204: 399-412.

Harms, K.E., Powers, J.S. \& Montgomery, R.A. 2004. Variation in small sapling density, understory cover, and resource availability in four neotropical forests. Biotropica 36: 40-51.

Harper, J.L. 1977. Population biology of plants. Academic Press, London. 892 p.

Hart, T.B. 1995. Seed, seedling and sub-canopy survival in monodominant and mixed forests of the Ituri Forest, Africa. Journal of Tropical Ecology 11: 443-459.

Hladik, A. \& Mitja, D. 1996. Seedlings, saplings and tree temperaments: potential for agroforestry in the african rain forest. In: Swaine, M.D. (ed.). The ecology of tropical forest tree seedlings. Man and the biosphere series v. 17. Parthenon Publishing, New York. Pp. 173-192.

Howe, H.F. \& Smallwood, J. 1982. Ecology of seed dispersal. Annual Review of Ecology and Systematics 13: 201-228.

Hubbell, S.P. \& Foster, R.B. 1987. La estructura espacial en gran escala de un bosque neotropical. Revista de Biología Tropical 35(suppl. 1): 7-22.

Jardim, F.C.S.; Serrão, D.R. \& Nemer, T.C. 2007. Efeito de diferentes tamanhos de clareiras, sobre o crescimento e a mortalidade de espécies arbóreas, em Moju-PA. Acta Amazonica 37: 37-48.
King, D.A.; Davies, S.J. \& Noor, N.S.Md. 2006. Growth and mortality are related to adult tree size in a Malaysian mixed dipterocarp forest. Forest Ecology and Management 223: 152-158.

Knight, D.H. 1975. A phytosociological analysis of species-rich tropical forest on Barro Colorado Island, Panama. Ecological Monographs 45: 259-284.

Laurance, W.F.; Nascimento, H.E.M.; Laurance, S.G.; Condit, R.; D’Angelo, S. \& Andrade, A. 2004. Inferred longevity of Amazonian rainforest trees based on a long-term demographic study. Forest Ecology and Management 190: 131-143.

Lee, D.W. 1996. Irradiance and spectral quality affect Asian tropical rain forest tree seedling development. Ecology 77: 568-580.

Leite, E.J. \& Hay, J.D. 1989. Regeneração natural de garapa, Apuleia leiocarpa (Vog.) Macbr., numa reserva genética. Ciência e Cultura 41: 804-807.

Leite, A.M.C. \& Salomão, A.N. 1992. Estrutura populacional de regenerantes de copaíba (Copaifera langsdorffii Desf.) em mata ciliar do Distrito Federal. Acta Botanica Brasilica 6:123-134.

Lieberman, D. 1996. Demography of tropical tree seedlings: a review. In: Swaine, M.D. (ed.). The ecology of tropical forest tree seedlings. Man and the Biosphere Series. Vol. 17. Parthenon Publishing, New York. Pp. 131-139.

Lima, R.A.F. 2005. Estrutura e regeneração de clareiras em Florestas Pluviais Tropicais. Revista Brasileira de Botânica 28: 651-670.

Mack, A.L.; Ickes, K.; Jessen, J.H.; Kennedy, B. \& Sinclair, J.R. 1999. Ecology of Aglaia mackiana (Meliaceae) seedlings in a New Guinea rain forest. Biotropica 31: 111-120.

Meyer, S.T.; Silva, A.F.; Marco-Júnior, P. \& MeiraNeto, J.A.A. 2004. Composição florística da vegetação arbórea de um trecho de floresta de galeria do Parque Estadual do Rola-Moça na Região Metropolitana de Belo Horizonte, MG, Brasil. Acta Botanica Brasilica 18: 701-709.

Molofsky, J. \& Augspurger, C.K. 1992. The effect of leaf litter on early seedling establishment in a tropical forest. Ecology 73: 68-77.

Montgomery, R.A. 2004. Effects of understory foliage on patterns of light attenuation near the forest floor. Biotropica 36: 33-39.

Mori, S.A. \& Prance, G.T. 1990. Flora Neotropica. Lecythidaceae. Part II: The Zigomorphic-flowered New World Genera (Couroupita, Corythophora, Bertholletia, Couratari, Eschweilera \& Lecythis). Monograph 21 (II). New York Botanical Garden, New York. 376p.

Muthuramkumar, S.; Ayyappan, N; Parthasarathy, N.; Mudappa, D.; Raman, T.R.S.; Selwyn, M.A. \& Pragasan, L.A. 2006. Plant community structure in 
tropical rain forest fragments of the Western Ghats, India. Biotropica 38: 143-160.

Nunes, Y.R.F., Ribeiro, V.F. 1999. Influência da luz e armazenamento na germinação de sementes de Cariniana estrellensis (Raddi) Kuntze. In: 13 Jornada de Biologia e $1^{\circ}$ Encontro de Biólogos do CRBio - 4a Região, 1999, Belo Horizonte. Resumos. Pontifícia Universidade Católica de Minas Gerais e Conselho Regional de Biologia $4^{\mathrm{a}}$ Região, Belo Horizonte. Pp. 23-24.

Oliveira-Filho, A.T. \& Galetti, M. 1996. Seed predation of Cariniana estrellensis (Lecythidaceae) by black howler monkeys, Alouatta caraya. Primates 37: 87-90.

Oliveira-Filho, A.T.; Vilela, E.A.; Carvalho, D.A. \& Gavilanes, M.L. 1994. Effects of soils and topography on the distribution of tree species in a tropical riverine forest in south-eastern Brazil. Journal of Tropical Ecology 10: 483-508.

Oliveira, M.A.; Santos, A.M.M. \& Tabarelli, M. 2008. Profound impoverishment of large-tree stand in a hyper-fragmented landscape of Atlantic forest. Forest Ecology and Management 256: 1910-1917.

Peres, C.A. \& Baider, C. 1997. Seed dispersal, spatial distribution and population structure of brazilnut trees (Bertholletia excelsa) in southeastern Amazonia. Journal of Tropical Ecology 13: 595-616.

Poorter, L.; Bongers, F.; van Rompaey, R.S.A.R. \& Klerk, M. 1996. Regeneration of canopy tree species at five sites in West African moist forest. Forest Ecology and Management 84: 61-69.

Prance, G.T. \& Mori, S.A. 1979. Flora Neotropica. Lecythidaceae. Part 1. The Actinomorphic-flowered New World Lecythidaceae (Asteranthus, Gustavia, Grias, Allantoma \& Cariniana). Monograph 21 (I). New York Botanical Garden, New York. 270 p.

Ramos, F.N., Matos, D.M.S. \& Santos, F.A.M. 2005. Spatial distribution of seeds and juveniles of Enterolobium glaziovii Bentham (Leguminosae, Mimosoideae) in the Atlantic Forest, Brazil. Acta Botanica Brasilica 19: 609-614.

Rees, M.; Condit, R.; Crawley, M.; Pacala, S. \& Tilman, D. 2001. Long-term studies of vegetation dynamics. Science 293: 650-655.

Reitz, R. 1981. Flora ilustrada catarinense-Lecitidáceas. Herbário Barbosa Rodrigues, Santa Catarina. 32p.

Rizzini, C.T. 1971. Árvores e madeiras úteis do Brasil: manual de dendrologia brasileira. Edgard Blücher, São Paulo. 294p.
Salles, J.C. \& Schiavini, I. 2007. Estrutura e composição do estrato de regeneração em um fragmento florestal urbano: implicações para a dinâmica e a conservação da comunidade arbórea. Acta Botanica Brasilica 21: 223-233.

Santos, B.A.; Peres, C.A.; Oliveira, M.A.; Grillo, A.; Alves-Costa, C.P. \& Tabarelli, M. 2008. Drastic erosion in functional atributes of tree assemblages in Atlantic forest fragments of northeastern Brazil. Biological Conservation 141: 249-260.

Schupp, E.W.; Howe, H.F. \& Augspurger, C.K. 1989. Arrival and survival in tropical treefall gaps. Ecology 70: 562-564.

Silvertown, J.W. \& Lovett-Doust, J. 1993. Introdution to plant population biology. Blackwell Science, Oxford. 210 p.

Still, M.J. 1996. Rates of mortality and growth in three groups of dipterocarp seedlings in Sabah, Malaysia. In: Swaine, M.D. (ed.). The ecology of tropical forest tree seedlings. Man and the Biosphere Series. Vol. 17. Parthenon Publishing, New York. Pp. 315-332.

Swaine, M.D. \& Whitmore, T.C. 1988. On the definition of ecological species groups in tropical rain forest. Vegetatio 75: 81-86.

ter Steege, H. 1993. Hemiphot: a programme to analyse vegetation indices, light and light quality from hemispherical photographs. Tropenbos Documents, n. 3. University Utrecht, The Netherlands. 44p.

Wada, N. \& Ribbens, E. 1997. Japanese maple (Acer palmatum var. matsumurae, Aceraceae) recruitment patterns: seeds, seedling, and saplings in relation to conspecific adult neighbors. American Journal of Botany 84: 1294-1300.

Whitmore, T.C.; Brown, N.D.; Swaine, M.D.; Kennedy, D.; Goodwin-Bailey, C.I. \& Gong, W.K. 1993. Use of hemispherical photographs in forest ecology: measurement of gap size and radiation totals in Bornean tropical rain forest. Journal of Tropical Ecology 9: 131-151.

Zar, J.H. 1996. Biostatistical analysis. Prentice-Hall, New Jersey. 662p.

Zavala, M.A.; Angulo, O.; de la Parra, R.B. \& LópezMarcos, J.C. 2007. An analytical model of stand dynamics as a function of tree growth, mortality and recruitment: the shade tolerance-stand structure hypothesis revisited. Journal of Theoretical Biology 244: 440-450. 